\title{
EFFEKTIVITAS INFUSA AKAR MANIS SEBAGAI ANTI TUKAK LAMBUNG TIKUS YANG DIINDUKSI ASETOSAL
}

\author{
Joko Santoso \\ Poltekkes Permata Indonesia Jogyakarta
}

\begin{abstract}
The use of NSAID-class drugs such as acetosal is widely used by the community, which can cause peptic ulcers. Gastric ulcers are damaged in the mucosal and sub mucosal tissues. Indonesia is rich in traditional medicinal ingredients such as liquorice that can serve as an ingredient of anti ulcers. The purpose of this study is to determine the effect of the effectiveness of the extract of sweet root as gastroprotektor. Design of laboratory experiment post test with control. A total of 30 male Wistar strains of 2-3 months old, with 100-250 gram weight divided into 6 groups, each group consisted of 5 randomly divided animal animals, ie KI (sweet root) $5 \mathrm{mg} / 200 \mathrm{~g} \mathrm{BB}$ ), K.II (sweet root $10 \mathrm{mg} / 200 \mathrm{~g} \mathrm{BB}$ ), K.III (sweet root $15 \mathrm{mg} / 200 \mathrm{~g} \mathrm{BB}$ ), K. IV (sucralfat $72 \mathrm{mg} / 200 \mathrm{~g} \mathrm{BB}$ ), K. V (acetosal $90 \mathrm{Mg} / 200 \mathrm{~g} \mathrm{BB}$ ) and K.VI (without treatment). All treatments were administered orally for seven days. Observations were macroscopic and microscopic gastric mice. The results of the study: Group III had the greatest gastroprotector compared with other groups as indicated by the number of lesions, lesion area, damage score, number of mast cells and eosinophil cells were lower than those given the assetosal group ( $p<0.05)$
\end{abstract}

Keywords: Sweet Root, Gastroprotective And Gastric Ulcers.

Abstrak: Penggunaan obat-obatan golongan OAINS seperti asetosal sangat banyak dipergunakan oleh masyarakat sehingga dapat menyebabkan tukak lambung. Tukak lambung merupakan kerusakan pada jaringan mukosa dan sub mukosa. Indonesia kaya akan bahan obat tradisional seperti akar manis yang dapat berfungsi sebagai bahan obat anti tukak lambung. Tujuan penelitian ini adalah untuk mengetahui pengaruh keefektifan pemberian ekstrak akar manis sebagai gastroprotektor. Desain penelitian ini experiment laboratory post test design with control, Sebanyak 30 ekor tikus putih jantan galur Wistar berumur 2-3 bulan, dengan berat badan 100-250 gram terbagi menjadi 6 kelompok, tiap kelompok terdiri dari 5 hewan uji terbagi secara random yaitu K.I (akar manis $5 \mathrm{mg} / 200 \mathrm{~g} \mathrm{BB}$ ), K.II (akar manis $10 \mathrm{mg} / 200 \mathrm{~g} \mathrm{BB}$ ), K.III (akar manis $15 \mathrm{mg} / 200 \mathrm{~g}$ BB), K.IV (sukralfat $72 \mathrm{mg} / 200 \mathrm{~g} \mathrm{BB}$ ), K. V (asetosal $90 \mathrm{mg} / 200 \mathrm{~g} \mathrm{BB}$ ) dan K.VI (tanpa perlakuan). Semua perlakuan diberikan secara oral selama tujuh hari. Pengamatan berupa makroskopik dan mikroskopik lambung tikus. Hasil penelitian : Kelompok III mempunyai gastroprotektor terbesar dibanding dengan kelompok lain ditunjukkan dari jumlah lesi, luas lesi, skor kerusakan, jumlah sel mast dan sel eosinofil lebih rendah bila dibandingkan kelompok yang diberikan asetosal $(\mathrm{p}<0,05)$.

Kata Kunci : Akar Manis,Tukak Lambung Dan Gastroprotektif. 


\section{PENDAHULUAN}

Obat anti inflamasi nonosteroid (OAINS) merupakan kelompok obat yang paling banyak dikonsumsi diseluruh dunia untuk mendapatkan efek analgetik, antipiretik dan anti inflamasi. Obat ini merupakan salah satu kelomok obat yang paling banyak diresepkan dan digunakan tanpa resep dokter. Salah satu obat OAINS yang sering digunakan dan merupakan prototipe awal adalah asetosal (Wilmana dan Gan, 2007). Obat ini sering digunakan oleh masyarakat untuk mengobati penyakit sendi, rhematoid arthritis dan mengatasi rasa nyeri. Obatobat ini mempunyai efek iritasi pada mukosa lambung, berakibat perdarahan lambung yang berakhir dengan timbulnya tukak lambung (Tarigan, 2006 ; Hirlan, 2006).

Tukak lambung dapat terjadi karena adanya ketidak seimbangan dari faktor agresif (asam lambung dan pepsin) dan faktor defensif (sekresi mukosa, sekresi bikarbonat, aliran darah mukosa dan regenerasi epitel). Salah satu contoh penyebab terjadinya tukak lambung adalah asetosal yang merupakan suatu Obat Anti Inflamasi Non Steroid (OAINS) yang sejak lama banyak digunakan sebagai analgesik pilihan pertama. Hal yang dapat ditimbulkan akibat tukak lambung yaitu terjadi kematian sel atau nekrosis yang menyebabkan reaksi inflamasi (Neal, 2006). Tukak lambung adalah kerusakan pada jaringan mukosa, sub mukosa sampai lapisan otot lambung, penyebab tukak lambung diantaranya hipersekresi asam lambung sehingga terjadi kerusakan mukosa pada lambung (Ramakrishnan dan Salnas, 2007). Cara pencegahan terbentuknya tukak lambung diantaranya dengan cara pemberian obat yang dapat berfungsi sebagai sitoprotektif pada mukosa lambung, penghambatan pompa proton atau antagonis- $\mathrm{H} 2$, analog prostaglandin dan penurunan motilitas lambung (Neal, 2006). Obatsitoprotektif (pelindungmukosa) merupakan obat yang berfungsi sebagai lapisanpelindung mukosa lambung. Salah satu obat sitoprotektif mukosa lambung yang sering digunakan adalah sukralfat. Penggunaan sukralfat sebagai obat kimia bukan berarti tanpa risiko. Ada efek samping yang ditimbulkan dan perlu mendapat perhatian diantaranya konstipasi, insomnia, gatalgatal, sakit perut dan muntah. Oleh sebab itulah perlu alternatif obat pengganti yang lebih aman, yang salah satunya berasal dari herbal (BPOM, 2008).

Akar manis (G. glabraLinn.) mempunyai kandungan saponin yang lebih dikenal dengan Glycyrrhizin yang berfungsi sebagai gastroprotektif (Depkes RI, 1979). Glisirisin adalah konstituen aktif yang menghasilkan aktivitas anti ulkus dengan cara menginhibisi 15hidroksi prostaglandin dehidrogenase dan prostaglandin reduktase. Penghambatan kedua enzim tersebut merangsang terjadinya peningkatan konsentrasi prostaglandin E dan F2 $\alpha$ dilambung yang memacu penyembuhan peptik karena efek sitoprotektif pada mukosa lambung (WHO, 2002; Wijayanti, 2013). Dalam penelitian ini akar manis (G. glabra) akan dibuat dalam sediaan infusa. Pemakaian infusa yang murah dan mudah digunakan oleh masyarakatmenjadi salah satu alasannya. Selain itu belum adanya data ilmiah mengenaicampuran ketiga bahan tersebut dalam mengatasi masalah tukak lambung.Berdasarkan uraian tersebut di atas maka penelitian ini ingin menilai pengaruhdari infusa akar manis $(G$. glabra) terhadap daya gastroprotektifmukosa lambung dan 
gambaran histopatologi untuk mengamati kerusakanstruktur jaringannya serta mengetahui jumlah sel mast pada jaringan lambungtikus model tukak lambung yang diinduksi asetosal.

\section{METODE PENELITIAN}

Jenis penelitian ini adalah exsperimental laboratory. Rancangan penelitian yang digunakan adalah Randomized post test group with control. Penelitian ini dilaksanakan di Laboratorium Farmakognosi Departemen Biologi Farmasi Universitas Gadjah Mada.Laboratorium Penelitian dan Pengujian Terpadu 4 (LPPT 4) Universitas Gadjah Mada Yogyakarta dan Laboratorium Histologi Fakultas Kedokteran hewan Universitas Gadjah Mada Yogyakarta.

Hewan uji yang digunakan dalam penelitian ini adalah tikus putih (Rattus norwegia) jantan, galur Wistar. Kriteria hewan uji dalam penelitian ini adalah jenis kelamin jantan, umur 2-3 bulan, berat badan 100-200 gram, sehat yang memiliki ciri yaitu gerak aktif dan nafsu makan baik, tidak ada kelainan anatomi maupun fisik. Jumlah hewan uji terbagi 8 kelompok perlakuan dan tiap kelompok terdiri dari 5 ekor tikus, jadi jumlah total hewan uji adalah $8 \times 5$ ekor $=40$ ekor tikus wistar. Sebanyak 40 ekor tikus jantan dikelompokkan secara acak menjadi 6 kelompok masing-masing 5 ekor. Dosis penelitian ini adalah infusa akar manis yaitu ekstrak akar manisdosis5 $\mathrm{mg} / 200 \mathrm{gr}$ BB (K. I), ekstrak akar manisdosis10 mg/200gr BB (K. II), ekstrak akarmanisdosis $15 \mathrm{mg} / 200 \mathrm{gr} \mathrm{BB}$ (K. III), kontrolpositif (K. VI)dosis (sukralfat $72 \mathrm{mg}$ ) /200gr BB, kontrolnegatif (K. VII) dosis (asetosal 90 $\mathrm{mg} \mathrm{/} 200$ gr BB) dan normal (tanpainduksidanpemberianobat)

(K. VIII). Infusa ramuan dan sukralfat diberikan setiap hari pada jam 09.00 WIB selama 7 hari berturut-turut kemudian setelah 10 menit perlakuan tersebut maka masing-masing diinduksi dengan asetosal. Pada hari ke-8 hewan uji dipuasakan selama 24 jam dengan pemberian minum ad libitum (Arifa, 2009).

Identifikasi tanaman ini dilakukan di Laboratorium Farmakognosi Bagian Biologi Farmasi Fakultas Farmasi Universitas Gadjah Mada Yogyakarta. Asal-usul bahan untuk penelitian yaitu akarmanis (G. glabraLinn.) didapatkan dari Pasar Gede Solo. Uji saponin dilakukan dengan metode Uji Forth yaitu ekstrak akar manis ditimbang sebanyak 20 mg, lalu ditambahkan $20 \mathrm{ml}$ air panas kemudian dikocok kuat secara vertikal selama 10 detik. Setelah dilakukan pengocokan secara vertikal, maka akan terbentuk buih setinggi $1-10 \mathrm{~cm}$ selama 10 menit. Kemudian ditambahkan 1 tetes HCL 2N dan dimati (Guevara \& Recio, 1985).

Data yang diperoleh akan diproses menggunakan program komputer SPSS. Uji normalitas data dengan Saphiro Wilk. Jika sebaran data normal maka diteruskan dengan uji parametrik Oneway Anova dan dilanjutkan dengan Post hoc tukey. Apabila sebaran data tidak normal maka diteruskan dengan uji non parametrik Kruskal Wallis dan kemudian dilanjutkan dengan analisis Mann Whitney. Nilai signifikan dalam penelitian ini adalah $\mathrm{p}<0,05$.

\section{HASIL PENELITIAN}

1. Identifikasi Simplisia

Simplisia dalam penelitian akar manis (G. glabra Linn.) dibeli dari pasar Gede Solo. Tujuan dari 
identifikasi penelitian ini adalah untuk memastikan kebenaran dan kejelasan bahan yang digunakan untuk penelitian. Identifikasi bahan tanaman dalam penelitian ini dilakukan di Laboratorium Farmakognosi , Departement Bagian Biologi Farmasi, Universitas Gadjah Mada Yogyakarta. Hasil identifikasi tanaman menunjukkan bahwa bahan yang digunakan adalah benar di Laboratorium Farmakognosi departement Biologi Farmasi, Universitas Gadjah Mada Yogyakarta.

2. Pembuatan Ekstrak Tanaman

Infusa dibuat dari tanaman akar manis (G. glabra Linn.). Metode Infudasi dipilih karena mempertimbangkan kemudahan dalam pembuatannya. Cairan penyari yang digunakan adalah air yang mudah didapatkan, tidak beracun, netral, serta mudah menarik keluar senyawa aktif dalam sel, suhu $90^{\circ}$ Celcius selama 15 menit (Donatus et al., 1992).

\section{Tabel 1}

\section{Data Hasil Ekstraksi Tanaman}

\begin{tabular}{cccc}
\hline $\begin{array}{c}\text { Nama } \\
\text { sampel }\end{array}$ & $\begin{array}{c}\text { Berat } \\
\text { bahan } \\
(\mathrm{gr})\end{array}$ & $\begin{array}{c}\text { Berat } \\
\text { ekstrak } \\
(\mathrm{gr})\end{array}$ & $\begin{array}{c}\text { Rendemen } \\
(\%)\end{array}$ \\
\hline $\begin{array}{c}\text { Akar } \\
\text { Manis }\end{array}$ & 500 & 7,08 & 1,416 \\
\hline
\end{tabular}

\section{Tabel 2}

Data Hasil Uji Organoleptik Ekstrak

\begin{tabular}{cccc}
\hline Nama & & & \\
Sampel & Warna & Bau & Rasa \\
\hline Akar Manis & $\begin{array}{c}\text { Coklat } \\
\text { kehitaman }\end{array}$ & Aromatis & $\begin{array}{c}\text { Sangat } \\
\text { manis }\end{array}$ \\
\hline
\end{tabular}

\section{Uji Kandungan Kimia}

Uji saponin dilakukan dengan metode Uji Forth yaitu ekstrak akar manis ditimbang sebanyak $20 \mathrm{mg}$, lalu ditambahkan $20 \mathrm{ml}$ air panas kemudian dikocok kuat secara vertikal selama 10 detik. Setelah dilakukan pengocokan secara vertikal, maka akan terbentuk buih setinggi $1-10 \mathrm{~cm}$ selama 10 menit. Kemudian ditambahkan 1 tetes HCL $2 \mathrm{~N}$ dan dimati (Guevara \& Recio, 1985). Hal ini menunjukkan bahwa sampel akar manis (G. glabra Linn.) memiliki kandungan senyawa saponin. Busa terbentuk dikarenakan adanya kandungan glikosidan yang memiliki kemampuan membentuk busa dalam air yang terhidrolisis menjadi glukosa (Chaniago, 2003).

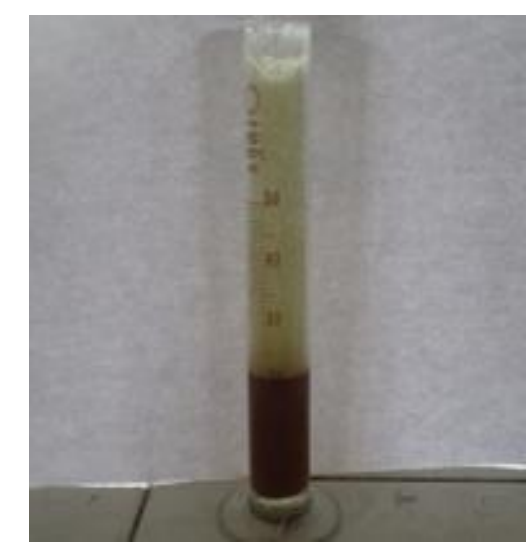

Gambar 1. Uji kandungan saponin (metode uji Forth)

Dalam gambar hasil uji forth diatas didapatkan bahwa tanaman akar manis (G. glabra) tersebut mengandung senyawa saponin karena terbentuk buih yang mantap setinggi diatas $10 \mathrm{~cm}$ selama 10 menit kemudian ditambahkan 1 tetes HCL $2 \mathrm{~N}$ maka tinggi buih yang dihasilkan tidak mengalami penurunan. Timbulnya busa pada uji saponin ini menunjukkan adanya glikosida yang mempunyai kemampuan nenbentuk buih dalam air yang terhidrolisis menjadi glukosa dan senyawa lainnya (Guevara \& Recio, 1985). Reaksi pembentukan busa : 


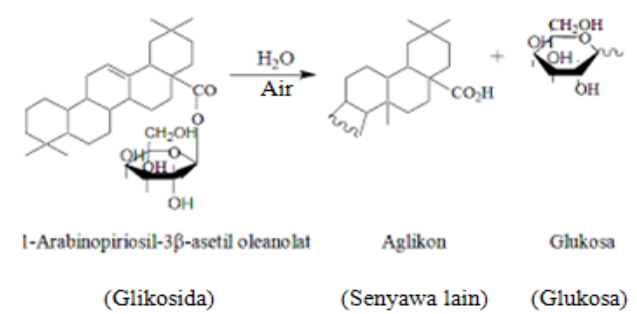

Gambar 2. Reaksi hidrolisis saponin dalam air (Guevara \& Recio, 1985).

4. Histologi Jaringan Lambung Tikus yang diinduksi Asetosal
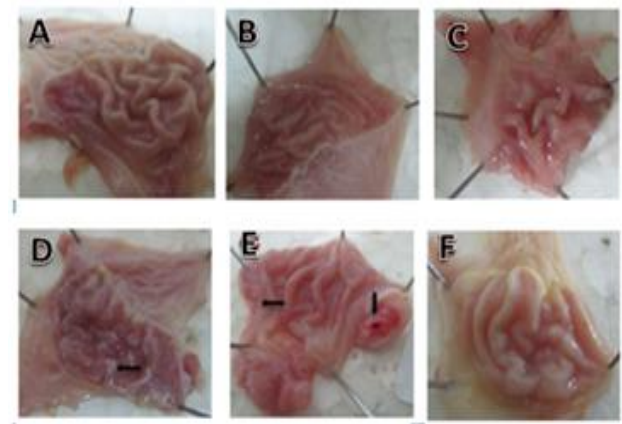

Gambar 3. Makroskopik mukosa lambung.

Keterangan : $\mathrm{A}=$ akar manis $5 \mathrm{mg}$ (K.I), $\mathrm{B}=$ akar manis $10 \mathrm{mg}$ (K.II), C = akar manis $15 \mathrm{mg}$ (K.III), D = sukralfat $/$ kontrol positif (K.IV), $\mathrm{E}=$ asetosal $/$ kontrol negatif (K.V), $\mathrm{F}=$ normal tanpa perlakuan apapun (K.VI), tanda panah $(\rightarrow)=$ menunjukkan lesi pada kelompok perlakuan.

Tabel 3

\section{Data Hasil Pengamatan Jumlah Lesi}

\begin{tabular}{cccc}
\hline Kelompok & Mean (SD) & $\begin{array}{c}\text { Nilai p } \\
\text { (Mann- } \\
\text { whitney)) }\end{array}$ & $\begin{array}{c}\text { Nilai p } \\
\text { (Kruskall- } \\
\text { Wallis) })\end{array}$ \\
\hline I & $0,40(0,55)$ & 0,005 & 0,002 \\
II & $0,20(0,45)$ & 0,004 & \\
III & $0,00(0,00)$ & 0,003 & \\
IV & $0,20(0,45)$ & 0,004 & \\
V & $2,00(0,00)$ & - & \\
VI & $0,00(0,00)$ & 0,003 & \\
\hline
\end{tabular}

Tabel 4

Data Hasil Pengamatan Luas Lesi

\begin{tabular}{cccc}
\hline Kelompok & Mean (SD) & $\begin{array}{c}\text { Nilai p } \\
\text { (Mann- } \\
\text { whitney)) }\end{array}$ & $\begin{array}{c}\text { Nilai p } \\
\text { (Kruskall- } \\
\text { Wallis)) }\end{array}$ \\
\hline I & $3,52(4,83)$ & 0,008 & 0,003 \\
II & $0,92(1,35)$ & 0,008 & \\
III & $0,00(0,00)$ & 0,005 & \\
IV & $11,41(25,51)$ & 0,013 & \\
V & $106,21(50,66)$ & - & \\
VI & $0,00(0,00)$ & 0,005 & \\
\hline
\end{tabular}

1. Skor Kerusakan Lambung
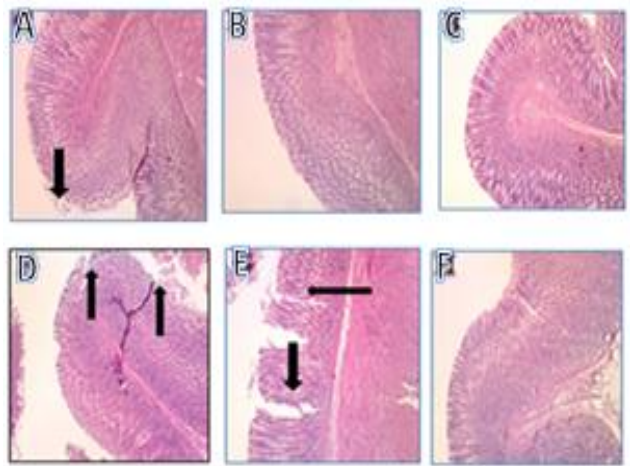

Gambar 4. Histopatologi jaringan lambung.

Keterangan : $\mathrm{A}=$ akar manis 5mg (K.I), $\mathrm{B}=$ akar manis $10 \mathrm{mg}$ (K.II), $\mathrm{C}=$ akar manis $15 \mathrm{mg}$ (K.III), D = sukralfat / kontrol positif (K.IV), $\mathrm{E}=$ asetosal / kontrol negatif $(\mathrm{K} . \mathrm{V}), \mathrm{F}=$ normal tanpa perlakuan apapun (K.VI), tanda panah $(\rightarrow)=$ menunjukkan erosi pada jaringan lambung.

\section{PEMBAHASAN}

Tukak lambung merupakan salah satu bentuk tukak peptik yang ditandai dengan rusaknya lapisan mukosa, bahkan sampai ke mukosa muskularis sehingga ketidakseimbangan antara faktor agresif dan protektif merupakan awal terjadinya tukak lambung dan hipersekresi asam lambung sebagai faktor agresif adalah kondisi patologis yang terjadi akibat 
sekresi $\mathrm{HCl}$ yang tidak terkontrol dari sel sel parietal mukosa lambung melalui pompa proton $\mathrm{H}^{+} / \mathrm{K}^{+}$ATPase, sedangkan kerusakan lapisan mukus yang berfungsi sebagai faktor protektif pada permukaan mukosa lambung dapat memperparah keadaan. Banyak kondisi yang menyebabkan ketidakseimbangan kedua faktor tersebut. Adanya reaksi yang berlebihan terhadap makanan tertentu, minuman yang mengandung kafein dan alkohol, rangsangan parasimpatis dan histamin dapat merangsang sel-sel parietal untuk menghasilkan $\mathrm{HCl}$. Penggunaan obat-obatan seperti antiinflamasi non steroid (AINS) berkaitan erat dengan terjadinya perdarahan lambung melalui iritasi sel-sel epitel secara langsung dan inihibi sistemik sintesis prostaglandin mukosa saluran pencernaan. Keberadaan Helicobacter pylori dapat mengganggu pertahanan mukosa melalui elaborasi toksin dan enzim serta meningkatkan pelepasan gastrin (Fadlina, 2008; Barbara, 2003).

Seperti yang terlihat pada gambar dibawah ini (Johnson, 2007) :

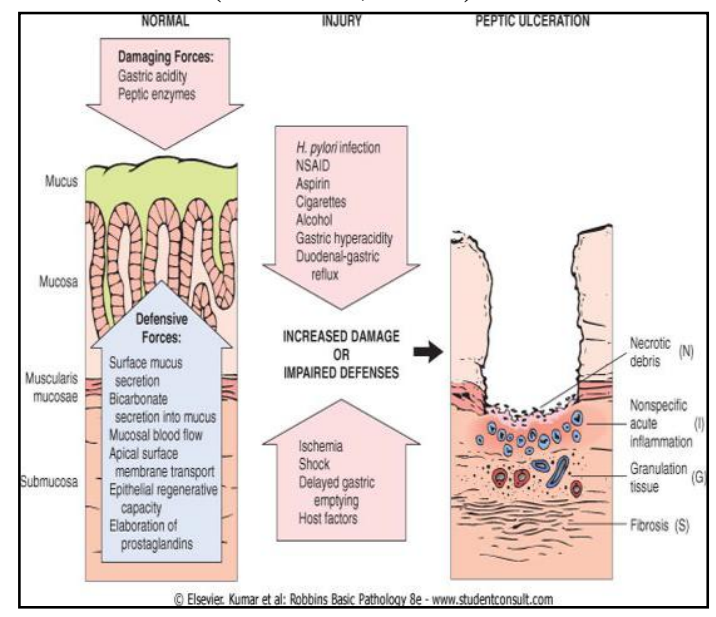

Gambar 5. Mekanisme terbentuknya tukak lambung dari gambar diatas terlihat bahwa di samping mekanisme keseimbangan faktor agresif dan faktor defensif tersebut di atas, terdapat faktor lain yang ikut berperan yakni keseimbangan neuro-hormonal dan berbagai peptida gastrointestinal lain (Robbin, 2005).

Patogenesis tukak lambung yang paling banyak berupa iritasi mukosa dimana terjadi peningkatan pengelupasan sel epitel permukaan akibat obat-obat yang mempunyai efek iritasi. Obat-obat tersebut antara lain; salisilat, digitalis, yodium, kafein, cinchophen, fenilbutazon, antibiotika yang mempunyai spektrum yang luas, NSAIDs, dan parasetamol dosis tinggi (Bahiyah, 2003; Underwood, 1999; Kasno, 2003). Parasetamol telah banyak digunakan sebagai obat antipiretik dan analgesik yang dipandang sebagai obat yang relatif aman untuk lambung (Setiabudy, 1995). Namun beberapa peneliti lain menyatakan pada dosis yang tinggi, parasetamol dapat menimbulkan iritasi, erosi, ulkus, dan perdarahan lambung seperti efek gastrointestinal obatobat NSAID (Kumar, 2005; Farel; Bahiyah, 2003).

Pada keadaan normal, asam lambung dan pepsin tidak akan menyebabkan kerusakan mukosa lambung dan duodenum. Bila oleh karena sesuatu sebab ketahanan mukosa rusak (misalnya karena salisilat, empedu, iskemia mukosa) maka akan terjadi difusi balik $\mathrm{H}^{+}$dari lumen masuk kedalam mukosa. Difusi balik $\mathrm{H}^{+}$akan menyebabkan reaksi berantai yang akan

menyebabkan kerusakan pada mukosa (Enaganti, 2006). Difusi balik $\mathrm{H}^{+}$akan menyebabkan pepsin dilepas dalam jumlah besar, $\mathrm{Na}^{+}$dan protein plasma banyak yang masuk kedalam lumen dan terjadi pelepasan histamin. Selanjutnya 
terjadi peningkatan sekresi asam lambung oleh sel parietal, peningkatan permeabilitas kapiler, oedema dan perdarahan. Di samping itu akan merangsang parasimpatik lokal akibat sekresi asam lambung makin meningkat dan tonus muskularis mukosa meninggi, sehingga kongesti vena makin hebat dan menyebabkan perdarahan. Keadaan ini yang dapat menyebabkan kerusakan mukosa makin berlanjut, dapat terjadi erosi superfisial atau ulserasi (Tarnawski, 2004). Iritasi pada mukosa yang berlangsung lama menyebabkan kerusakan mukosa yang berulang-ulang sehingga dapat terjadi radang lambung kronis dan tukak lambung. Hal ini terjadi misalnya pada pecandu alkohol, perokok, pengguna analgetik non steroid jangka panjang dan refluks empedu. Keadaan serupa terjadi juga pada fungsi pengosongan lambung yang lambat, sehingga mukosa lambung kontak lama dengan isi lambung (Sibuea WH, 2005).

Mukosa lambung dapat mengalami kerusakan oleh berbagai sebab salah satunya adalah dengan pemberian asetosal. Kerusakan lambung akibat asetosal dapat disertai berkurangnya glikoprotein mukus dan hipersekresi asam lambung. Terjadinya hipereksresi lambung dan pepsin atau berkurangnya mikrosirkulasi dari lambung menjadi penyebab utama timbulnya lesi mukosa lambung (Nadi, 1992). Peningkatan sel mast dan sel eosinofil adalah salah satu indikator adanya reaksi inflamasi dan alergi. Efek gastroprotektif yang baik ditandai dengan sel mast dan sel eosinofil. Sel-sel radang yang mula-mula keluar adalah netrofil dan makrofah. Selain makrofah dan neutrofil sistem pertahanan tubuh juga mengeluarkan sel mast dan leukosit lain yaitu eosinofil. Sel mast mengalami degranulasi dengan melepaskan mediator-mediator inflamasi karena adanya ulkus sedangkan eosinofil berperan dalam reaksi alergi.

Dari studi literatur dan jurnal penelitian ditemukan bahwa daun kelor mempunyai kandungan kaemferol dan flavonoid (kuersetin). Kuersetin berfungsi sebagai antioksidan yang mampu menstabilkan radikal bebas karena adanya gugus hidroksi fenolik (Daniel, 2006; Pokorny dkk, 2001), kuersetin memiliki aktivitas anti inflamasi dan efek gastroprotektif (Harbone, 2000). Tidak hanya itu, kuersetin dan kaemferol juga mempunyai potensi cukup baik dalam menghambat aktivitas enzim ksantin oksidase (Cos dkk., 1998). Untuk membedakan penelitian ini dengan penelitian-penelitian yang lalu adalah pada penelitian ini dilakukan dengan membuat campuran 3 bahan alam yaitu kunyit, akar manis dan daun kelor untuk diuji aktivitas gastroprotektif terhadap mukosa lambung yang diinduksi asetosal. Diharapkan dari penelitian ini akan didapatkan suatu formula yang memiliki daya gastroprotektif yang lebih baik namun memiliki efek samping yang lebih kecil.

\section{KESIMPULAN DAN SARAN}

\section{A. Kesimpulan}

Berdasarkan penelitian yang telah dilakukan , maka dapat disimpulkan sebagai berikut:

1. Pemberian ekstrak akar manis $(G$. glabra Linn.), dapat mencegah secara signifikan menurunkannya berat badan tikus, jumlah dan luas lesi, skor kerusakan lambung, jumlah sel mast, sel eusinofil pada mukosa dan 
submukosa lambung yang di induksi asetosal.

2. Pemberian ekstrak akar manis $(G$. glabra Linn) pada kelompok III memberikan hasil yang baik dibandingkan dengan dosis lainnya pada mencit yang diinduksi asetosal.

B. Saran

1. Perlu dilakukan penelitian lebih lanjut mengenai toksisitas dari pemberian ekstrak akar manis $(G$. glabra Linn.) terhadap lambung

\section{DAFTAR RUJUKAN}

Arifa D, 2009. Uji efek anti ulcer infusa umbi talas ( Calocasia Esculatumschoott) pada tikus putih jantan galur wistar, Tesis, Universitas Muhammadiyah Surakarta.

BPOM, 2008. Informatorium Obat Nasional Indonesia, 690-692

Barbara et al., 2003. Pharmacotherapy Handbook, 5th edition.Appleton \& Lange, USA : 268-270.

Cos P., Ying L., Calomme M., J. P., Cimanga K., Van Poel B., Pieters L., Vlietinck., A.J., dan Vanden Berghe, D., 1998, Structureactivity relationship and classification of flavonoids as inhibitors of xanthine oxidase and superoxide scavengers, J. Nat. Prod ., 61:71-76.

Daniel M, 2006. Medical plants chemistry and properties, science publishers, enfield, NH, USA

Dehpour A. R., Zolfaghari ME., Samadian, T., Vahedi Y, 1994, The protective effect of liquorice components and their derivatives against gastric ulcer induced by asetosal in rats, J Ethno Pharm, 46: 148-149.

Depkes RI, 1979. Materia medika Indonesia.Jilid III. Jakarta.

Depkes RI, 2008. Farmakope herbal indonesia, Edisi I, Jakarta.

Donatus I. A., Suhardjono D., Nurlaila., Sugiyanto., Hakim L., Wahyono D dkk., 1992. Petunjuk praktikum toksikologi, Laboratorium Farmakologi dan Toksikologi, Fakultas Farmasi, UGM, Yogyakarta edisi 1.

Enaganti S, 2006. Peptic ulcer disease. The disease and non-drug treatment. Hospital Pharmacist : 13: 239-42.

Fadlina C., Santi P.S., Abdul M., 2008. Pengembangan metode induksi tukak lambung. Majalah Ilmu Kefarmasian Vol V No 2 hal 8490. Departemen Farmasi FMIPA Universitas Indonesia

Farrel SE, Toxicity Acetamenophen. http://www.emedicine.com.emerg/ topic819.htm.

Harborne J. B., Williams C. A., 2000. Advances in flavanoid research since 1992, Departemen of Botany, Scool of plant sciences, The university of reading, Reading RG6 6AS, UK, Review, Phytochemistry, 55: 481 \pm 504 .

Hirlan, 2006. Gastritis. Dalam: Sudoyo AW, Setiyohadi B, Alwi I, Marcellussimadibrata,

Johnson A., Kratz B., Scanion L., Spivak A., Guts and Glory H. Pylori., 2007. Cause of peptic ulcer. Eukarion, 3: 67-72.

Kasno., Prasetyo A., 2003. Patologi rongga mulut \& traktus gastro intestinalis. Semarang: Badan 
Penerbit Universitas Diponegoro: 66-72.

Kumar V., Abbas AK., Fausto N editors., 2005. Pathologic basis of desease.7th edition. Philadelphia : Elsevier. 2 (17) :810-17.

Nadi Cos P., Ying L., Calomme, M., Hu, J. P., Cimangga K., Van Poe B., pieters L., Vlietinck A. J., vanden Berghe D., 1998. Struktur activity relationship and Classification of flavonoids as inhibitors of xanthine oxidase and superoxside scavengers, Journal of natural products, $61: 71 \pm 76$.

Neal, M. D. of Sidney , College of health sciences, School of Farmacy, Sidney, New South Wales, Australia

Neal MJ, 2006. Obat yang bekerja pada saluran gastrointestinal I: ulkus peptikum.

Ramakrishnan K., Salnas R. C., 2007. Peptic ulcer disease, American family physician, 7 :1005-12.

Setiabudy R., Suyatna FD., Purwantyastuti., Nafraldi., 1995. Farmakologi dan terapi. Edisi 4. Jakarta: Gaya Baru.207-10.
Sibuea WH., Panggabean MM., Gultom SP., 2005. Ilmu penyakit dalam. Edisi ke 2. PT Rineka Cipta, Jakarta:169-80.

Tarnawski AS., Caves TC., 2004. Aspirin in the XXI century: Its major clinical impact, novel mechanisms of action, and new safer formulation. Gastroenterology ; 127: 341-3.

Tarigan P., 2006. Tukak gaster. Dalam : Sudoyo AW., Setiyohadi B., Alwi I., Marcellussimadibrata., Setiati S., eds. Buku Ajar Ilmu Penyakit Dalam. Edisi ke-4 ,FKUI, Jakarta : 340-6.

Underwood JCE, 1999. Patologi umum dan sistematik, edisi 2. Alih bahasa : Sarjadi Jakarta : EGC : 26-7, 432, 483.

WHO, 2002. Monographs on selected medicinal plants, 1: 190-193.

Wijayanti A., 2013. Efektifitas gastroprotektif infusa ramuan akar manis (Glycyrrhiza glabra), kulit batang pulosari (Alyxia Reinwardtii BI) dan daun sembung (Blumea Balsamifera) pada tikus model tukak lambung. Tesis. Universitas Gadjah Mada. 